\title{
PENGARUH PENDEKATAN PEMBELAJARAN DAN KEMAMPUAN BERPIKIR TERHADAP KEMAMPUAN MENULIS PADA PESERTA DIDIK MADRASAH IBTIDAIYAH / SEKOLAH DASAR
}

\author{
Elsunarti \\ Program Magister Prodi PGMI UIN Sultan Syarif Kasim Riau \\ Kampus: Jalan KH. Ahmad Dahlan No. 94 Pekanbaru Riau \\ Email: elsunarti@yahoo.com
}

\begin{abstract}
Abstrak:
Pendidikan di sekolah dasar bertujuan agar siswa bisa mendapatkan pemahaman, keterampilan, dan keahlian dalam hidup. Agar siswa dapat mmperoleh pemahaman, keterampilan dan keterampilan belajar yang dibutuhkan, harus disertai dengan pendekatan pembelajaran yang dapat menarik minat siswa. Pendekatan dalam pembelajaran dapat meningkatkan kreatifitas berfikir siswa. Kemampuan pemecahan masalah, pemikiran kritis dan pemikiran kreatif menjadi kebutuhan bagi siswa untuk menghadapi dunia nyata. Menulis adalah salah satu tuntutan yang harus dimiliki dalam proses belajar siswa. Menulis adalah bentuk kemampuan berbicara dan kemampuan berbahasa setelah mendengarkan, kemampuan berbicara, dan membaca. Kemampuan berpikir dan bernalar sangat erat kaitannya dengan pemikiran kritis. Kemampuan berpikir kritis di Madrasah Ibtidaiyah (MI)/Sekolah Dasar (SD) akan lebih menekankan pada belajar mandiri dan kreativitas yang bermuara pada perbaikan proses pendidikan.
\end{abstract}

\begin{abstract}
:
Education in primary schools is aimed at getting students to gain understanding, skills and skills in life. In order for students to obtain the necessary understanding, skills and learning skills, it must be accompanied by a learning approach that can attract students' interest. Approach in learning can improve student's thinking creativity. Problem solving skills, critical thinking and creative thinking become the need for students to face the real world. Writing is one of the demands that must be had in the learning process of students. Writing is a form of speech and language skills after listening, speaking, and reading. The ability to think and reason is closely related to critical thinking. The ability to think critically in Madrasah Ibtidaiyah (MI)/Elementary School (SD) will be more emphasis on self-learning and creativity that leads to improvement of the educational process.
\end{abstract}

\section{Kata kunci: \\ Pendekatan, Kemampuan, Pemikiran Kritis}

MENULIS merupakan bukti kemampuan seseorang yang berpikir yang dinyatakan dalam bentuk tulisan sehingga dapat dibaca orang lain. Menulis merupakan suatu bentuk manifestasi kemampuan dan keterampilan berbahasa yang paling akhir dikuasai oleh pembelajar bahasa setelah kemampuan mendengarkan, berbicara, dan membaca. M. Subana (2009: 131) menyatakan bahwa menulis merupakan kegiatan pengungkapan gagasan secara tertulis. Lebih lanjut beliau menyatakan menulis boleh dikatakan keterampilan yang paling sukar bila dibandingkan dengan keterampilan berbahasa lainnya. 
Salah satu benchmark dalam melaksanakan unit pendidikan nasional adalah keterampilan berpikir kritis. Ketrampilan berpikir kritis dapat dilaksanakan di sekolah sesuai dengan kebutuhan dan karakteristik peserta didik. Agar implementasi berpikir kritis dapat berjalan dengan baik, seluruh warga sekolah harus berperan penuh untuk lebih mengefektifkan keberhasilan dalam kemampuan berpikir kritis. Pendekatan pembelajaran yang menggunakan ketrampilan berpikir kritis dapat diusulkan untuk mencapai tujuan yang lebih bermakna. Dengan demikian, tujuan pengajaran berpikir kritis di Madrasah Ibtidaiyah (MI)/Sekolah Dasar (SD) akan lebih menekankan pada belajar mandiri dan kreativitas yang bermuara pada perbaikan proses pendidikan di lndonesia.

Menurut Plato, berpikir adalah berbicara dalam hati. Kalimat di atas dapat diartikan bahwa berpikir merupakan proses kejiwaan yang menghubung-hubungkan atau membanding-bandingkan antara situasi fakta, ide atau kejadian dan fakta, ide atau kejadian lainnya. Setelah proses berpikir itu, seseorang memperoleh suatu kesimpulan hasil pemikirannya. Menurut Dewey dalam Kokom Komalasari, berpikir dimulai apabila seseorang dihadapkan pada suatu masalah (perplexity) dan menghadapi sesuatu yang menghendaki adanya jalan keluar. Situasi yang menghadapi adanya jalan keluar tersebut, mengundang yang bersangkutan untuk memanfaatkan pengetahuan, pemahaman, atau keterampilan yang sudah dimilikinya terjadi suatu proses tertentu di otaknya sehingga ia mampu menemukan sesuatu yang tepat dan sesuai untuk digunakan mencari jalan keluar terhadap masalah yang dihadapinya. Dengan demikian, yang bersangkutan melakukan proses yang dinamakan kegiatan berpikir.

Kondisi yang berkembang saat ini belum terlaksanakanya pembelajaran yang mengarah pada pemikiran kritis. Dalam pembelajaran, kita sering melihat terbatasnya aktivitas belajar peserta didik dan sangat dominannya peran guru dalam proses pembelajaran. Mengajar lebih tampak daripada kegiatan pembelajaran. Hal ini mengakibatkan lemahnya proses dan pengalaman belajar serta rendahnya hasil belajar. Proses pembelajaran seperti ini menimbulkan kebosanan dan kelelahan pikiran, keterampilan yang diperoleh hanyalah sebatas pengumpulan fakta-fakta dan pengetahuan abstrak. Peserta didik hanya sebatas menghafal, dengan kata lain proses belajar terperangkap kepada proses menghafalnya tanpa dihadapkan kepada masalah untuk lebih banyak berpikir dan bertindak, sehingga belajar hanya menyentuh pengembangan kognitif tingkat rendah, belum mengembangkan kemampuan berpikir tingkat tinggi. Pemahaman menjadi dangkal sehingga tidak dapat mengetahui pengetahuan lainnya yang justru dapat membantu untuk menyelesaikan masalah

\section{KAJIAN PUSTAKA}

\section{Pendekatan Pembelajaran}

Tujuan utama pembelajaran di MI/SD adalah membantu peserta didik memperoleh ide, pemahaman dan keterampilan (life skills) dan esensial sebagai warga negara. Keterampilan esensial yang perlu dimiliki peserta didik adalah kemampuan me- 
ngamati benda dan lingkungan sekitarnya, kemampuan mendengarkan, kemampuan berkomunikasi secara efektif, serta kemampuan menanggapi dan memecahkan masalah secara efektif. Semua ini memerlukan kreativitas yang tinggi bagi peserta didik.

Pendidikan adalah hak hidup setiap manusia untuk mencapai kesempurnaan. Dengan pendidikan, upaya pengembangan dan peningkatkan sumber daya manusia akan berkualitas. Pemberlakuan KTSP di sekolah memberikan otonomi yang luas bagi sekolah atau guru untuk mengembangkan pendidikan dan pembelajaran sesuai dengan karakteristik peserta didik dan sumber belajar yang ada di lingkungannya. Pemberdayaan lingkungan sekolah merupakan suatu pendekatan yang berusaha untuk meningkatkan keterlibatan peserta didik melalui pendayagunaan lingkungan sebagai sumber belajar. Pembelajaran yang sesuai dengan karakteristik peserta didik ini akan menjadi kegiatan pembelajaran yang menarik perhatian peserta didik. Materi pelajaran menjadi sangat kontekstual dengan kehidupan dan sangat bermanfaat bagi lingkungan (Mulyasa, 2008). Untuk mencapai tujuan pembelajaran, guru harus menerapkan model pembelajaran yang dapat memotivasi peserta didik dan mengarahkan peserta didik untuk meningkatkan kemampuan berpikir kritis mereka sehingga dapat memecahkan masalah dalam pembelajaran yang diberikan oleh guru. "Kemampuan berpikir kritis peserta didik dapat ditingkatkan dengan menerapkan pembelajaran yang berpusat pada peserta didik." (Aryana, 2009: 64)

Ketertarikan peserta didik dengan model pembelajaran yang sesuai karakteristik peserta didik dapat disebabkan oleh otentitas materi yang disampaikan sehingga bermakna bagi peserta didik itu sendiri. Model pembelajaran berbasis masalah (PBM) merupakan model belajar yang mengorganisasikan pembelajaran di sekitar pertanyaan dan masalah, melalui pengajuan situasi kehidupan nyata yang autentik, yang mendorong peserta didik untuk melakukan penyelidikan dan inkuiri, dengan menghindari jawaban sederhana, serta memungkinkan adanya berbagai macam solusi dari situasi tersebut.

Hal tersebut sejalan dengan pendapatnya Arends (2004) yang menyatakan bahwa dengan belajar berbasis masalah peserta didik akan mampu membangun pikiran mereka dan keterampilan pemecahan masalah, belajar berperan sebagai orang dewasa, dan menjadi pebelajar yang mandiri. Lebih lanjut dikatakan bahwa model pembelajaran ini juga dapat merangsang berpikir tingkat tinggi peserta didik dalam situasi berorientasi masalah, termasuk di dalamnya belajar bagaimana belajar

Beberapa penelitian telah membuktikan bahwa dengan pendidikan, sumber daya manusia akan meningkat. Putra (2011: 15), menyatakan bahwa salah satu upaya yang dapat dilakukan untuk meningkatkan sumber daya manusia adalah meningkatkan kualitas pendidikan yang berfokus pada pengembangan kemampuan berfikir peserta didik. Sementara itu, pemikiran kritis, kreatif, sistematis, dan logis dapat dikembangkan melalui pendidikan matematika. Hal ini sangat memungkinkan karena pembelajaran memiliki keterkaitan yang kuat dan jelas dengan pola pikir yang kritis.

Pembelajaran harus dapat mengaitkan antara teori di sekolah dengan realita di masyarakat. Apabila antara pembelajaran di sekolah dengan realita di masyarakat 
berbeda, maka peserta didik akan bingung dan ragu terhadap materi pelajaran yang diterimanya. Mengaitkan pengalaman kehidupan nyata anak dengan ide-ide dalam materi pelajaran menjadi lebih bermakna.

Berdasarkan hasil penelitian yang dilakukan menunjukkan bahwa kemampuan berpikir kritis peserta didik dapat terbentuk dengan metode pembelajaran yang sesuai dengan karakteristik peserta didik. Metode pembelajaran yang dapat meningkatkan kemampuan peserta didik antara lain: pembelajaran berbasis masalah, pendekatan matematika realistik (PMR), model pembelajaran inkuiri terbimbing berbasis lingkungan, pendekatan saintifik, model pembelajaran think pair share, dan The Development of Context-Based English Learning Resources.

\section{Berpikir Kritis}

Berpikir kritis adalah suatu aktivitas kognitif yang berkaitan dengan penggunaan nalar. Belajar untuk berpikir kritis berarti menggunakan proses-proses mental, seperti memperhatikan, mengkategorikan, seleksi, dan menilai/memutuskan.

Kemampuan dalam berpikir kritis memberikan arahan yang tepat dalam berpikir dan bekerja, dan membantu dalam menentukan keterkaitan sesuatu dengan yang lainnya dengan lebih akurat. Oleh sebab itu, kemampuan berpikir kritis sangat dibutuhkan dalam pemecahan masalah/pencarian solusi, dan pengelolaan proyek. Pengembangan kemampuan berpikir kritis merupakan integrasi beberapa bagian pengembangan kemampuan, seperti pengamatan (observasi), analisis, penalaran, penilaian, pengambilan keputusan, dan persuasi. Semakin baik pengembangan kemampuan-kemampuan ini, maka kita akan semakin dapat mengatasi masalah-masalah/proyek komplek dan dengan hasil yang memuaskan.

Berpikir kritis meliputi aktivitas-aktivitas: memperhatikan detil secara menyeluruh; mengidentifikasi kecenderungan dan pola seperti memetakan informasi, identifikasi kesamaan dan ketidaksamaan, dan lain-lain; mengulangi pengamatan untuk memastikan tidak ada yang terlewatkan; melihat informasi yang didapat dari berbagai sudut pandang; memilih solusi-solusi yang lebih disukai secara obyektif; mempertimbangkan dampak dan konsekuensi jangka panjang dari solusi yang dipilih.

Bagi peserta didik, berpikir kritis dapat berarti: mencari dimana keberadaan bukti terbaik bagi subyek yang didiskusikan; mengevaluasi kekuatan bukti untuk mendukung argumen-argumen yang berbeda; menyimpulkan berdasarkan buktibukti yang telah ditentukan; membangun penalaran yang dapat mengarahkan pendengar ke simpulan yang telah ditetapkan berdasarkan pada bukti-bukti yang mendukungnya; memilih contoh yang terbaik untuk lebih dapat menjelaskan makna dari argumen yang akan disampaikan; dan menyediakan bukti-bukti untuk mengilustrasikan argumen tersebut.

\section{Kemampuan Menulis}

Henry Guntur Tarigan (1982: 1) menjelaskan kemampuan menulis sangat erat hubungannya dengan tiga keterampilan lainnya, yaitu: berbicara, membaca, dan menyimak. Dalam memperoleh keterampilan berbahasa, biasanya kita melalui suatu hu- 
bungan urutan yang teratur. Mula-mula pada masa kecil, kita belajar menyimak bahasa kemudian berbicara, sesudah itu kita belajar membaca dan menulis. Keempat keterampilan tersebut pada dasarnya merupakan suatu kesatuan, merupakan catur tunggal. Berikut ini akan penulis jelaskan pengertian menulis menurut para ahli.

Iskandarwassid (2009: 248), menjelaskan menulis merupakan suatu bentuk manisfestasi kemampuan dan keterampilan berbahasa yang paling akhir dikuasai oleh pembelajar bahasa setelah kemampuan mendengarkan, berbicara, dan membaca. Dibandingkan dengan tiga kemampuan berbahasa yang lain, kemampuan menulis lebih sulit dikuasai bahkan oleh penutur asil bahasa yang bersangkutan sekalipun. Hal ini disebabkan kemampuan menulis menghendaki penguasaan berbagai unsur kebahasaan dan unsur di luar bahasa itu sendiri yang akan menjadi isi tulisan. Hal senada M. Subana (2009: 231), menyatakan menulis merupakan kegiatan pengungkapan gagasan secara tertulis. Lebih lanjut beliau menyatakan menulis boleh dikatakan keterampilan yang paling sukar bila dibandingkan dengan keterampilan berbahasa lainnya. Sedangkan Isnaini Leo (2006: 1) menyatakan bahwa menulis dapat didefinisikan sebagai suatu kegiatan penyampaian pesan dengan menggunakan bahasa tulis sebagai alat atau medianya. Pesan adalah isi yang terkandung dalam suatu tulisan. Tulisan merupakan sebuah simbol bahasa yang dapat dilihat dan disepakati pemakainya. Dengan demikian, dalam komunikasi tulis paling tidak terdapat unsur terlibat; penulis sebagai penyampai pesan (penulis), pesan atau isi tulisan, saluran atau media berupa tulisan, saluran atau media berupa tulisan dan pembaca sebagai penerima pesan. Hal senada yang dijelaskan oleh Slamet (2008: 1), bahwa menulis dapat didefinisikan sebagai suatu kegiatan penyampaian pesan (komunikasi dengan menggunakan bahasa tulis sebagai alat medianya). Morsey dalam buku karangan Puji Santosa (2005: 1), berpendapat bahwa menulis/mengarang merupakan keterampilan berbahasa yang kompleks. Untuk itu, perlu dilatihkan secara teratur dan cermat sejak kelas awal MI/SD. Menulis merupakan keterampilan berbahasa yang produktif dan ekspresif karena penulis harus terampil menggunakan morfologi, struktur bahasa, dan memiliki pengetahuan bahasa yang memadai. Pembelajaran menulis di MI/SD terdiri atas dua bagian sebagaimana layaknya pembelajaaran membaca, yakni menulis permulaan dan menulis lanjut (pendalaman). Menulis permulaaan diawali dari melatih peserta didik memegang alat tulis dengan benar, menarik garis, menulis huruf, suku kata, kata, kalimat sederhana dan seterusnya. Untuk menulis huruf, suku kata, kata dan kalimat sederhana biasanya diawali atau bersamaan dengan pembelajaran membaca permulaan. Contoh untuk belajar menulis /a/ peserta didik diperkenalkan dengan membaca bunyi /a/. Contoh untuk menulis lanjut dimulai dari menulis kalimat sesuai gambar, sesuai gambar, menulis paragraf sederhana, dan menulis karangan pendek dengan bantuan berbagai media dengan ejaan yang benar.

\section{Hubungan Pendekatan Pembelajaran dan Berpikir Kritis dengan Kemampuan me- nulis}

Kemampuan berpikir sangat dipegaruhi oleh pendekatan pembelajaran yang diberikan. Pendekatan pembelajaran yang lebih baik akan menghasilkan pembelajar- 
an yang pemikiran yang kritis. Nurhayati dkk. (2013) berdasarkan hasil penelitiannya menyimpulkan bahwa pendekatan dalam pembelajaran dapat meningkatkan kreativitas berpikir peserta didik. Kemampuan pemecahan masalah, berpikir kritis, dan berpikir kreatif merupakan hakekat tujuan pendidikan dan menjadi kebutuhan bagi peserta didik untuk menghadapi dunia nyata.

Kegiatan menulis tidak terlepas dari berpikir. Di dalam menulis, ada proses berpikir atau bernalar. Berpikir adalah kegiatan memroses data yang mengikutkan kinerja otak, fisik, dan psikis. Hal ini sering luput dari perhatian bahwa semua kegiatan atau pekerjaan dilakukan melalui berpikir, khususnya kegiatan menulis teks berita. Oleh karena itu, kemampuan berpikir peserta didik juga memengaruhi kondisi kemampuan mereka dalam menulis.

berpikir kritis adalah suatu kemampuan untuk bernalar dalam suatu cara yang terorganisasi. Berpikir kritis memungkinkan untuk memanfaatkan potensi dalam melihat masalah, memecahkan masalah, menciptakan, dan menyadari diri. Lalu, berpikir kritis sangat dibutuhkan di setiap kalangan dengan apapun pekerjaan yang dijalaninya.

Karena menulis adalah aktivitas bernalar, maka salah satu aplikasi berpikir kritis adalah dalam kegiatan menulis. Hal ini berarti bahwa hasil proses berpikir dapat disalurkan melalui menulis. Oleh karena itu, kemampuan berpikir kritis peserta didik juga terlihat dari tulisan yang dihasilkannya. Misalnya, dari kecermatannya menyusun gagasan menggunakan tata bahasa, ejaan, dan sebagainya. Hal ini senada dengan yang dinyatakan oleh Teopilus dalam Andriani (2013: 2) bahwa kemampuan berpikir kritis dapat diketahui melalui bentuk-bentuk aktivitas seperti berbicara dan menulis.

\section{SIMPULAN}

Pembelajaran di MI/SD untuk membantu peserta didik memperoleh ide, pemahaman dan keterampilan dan esensial sebagai warga negara. Keterampilan esensial yang perlu dimiliki peserta didik adalah kemampuan mengamati benda dan lingkungan sekitarnya, kemampuan mendengarkan, kemampuan berkomunikasi secara efektif, serta kemampuan menanggapi dan memecahkan masalah secara efektif. Semua ini memerlukan kreativitas yang tinggi bagi peserta didik.

Ketertarikan peserta didik dengan model pembelajaran yang sesuai karakteristik peserta didik dapat disebabkan oleh otentitas materi yang disampaikan sehingga bermakna bagi peserta didik itu sendiri. Model PBM merupakan model belajar yang mengorganisasikan pembelajaran di sekitar pertanyaan dan masalah, melalui pengajuan situasi kehidupan nyata yang autentik, yang mendorong peserta didik untuk melakukan penyelidikan dan inkuiri, dengan menghindari jawaban sederhana, serta memungkinkan adanya berbagai macam solusi dari situasi tersebut.

Dari penjelasan tersebut jelaslah bahwa pendekatan dalam pembelajaran akan berpengaruh dengan berpikir peserta didik. Kemampuan berpikir peserta didik akan berpengaruh terhadap hasil belajar peserta didik seperti kemampuan menulis. 
Menulis merupakan suatu bentuk manisfestasi kemampuan dan keterampilan berbahasa yang paling akhir dikuasai oleh pembelajar bahasa setelah kemampuan mendengarkan, berbicara, dan membaca. Kegiatan menulis tidak terlepas dari berpikir. Di dalam menulis ada proses berpikir atau bernalar. Kemampuan berpikir dan bernalar sangat erat kaitannya dengan berpikir kritis. Kemampuan dalam berpikir kritis memberikan arahan yang tepat dalam berpikir dan bekerja, dan membantu dalam menentukan keterkaitan sesuatu dengan yang lainnya dengan lebih akurat.

\section{DAFTAR PUSTAKA}

Andriani, S. (2013). "Hubungan Berpikir Kritis dengan Kemampuan Menulis Paragraf Argumentasi Peserta didik Kelas X SMA Negeri 1 Limapuluh Tahun Pembelajaran 2012/2013", Skripsi. Medan : FBS Unimed.

Iskandarwassid. (2009). Strategi Pembelajaran Bahasa. Bandung: PT Remaja Rosdakarya.

Nurhayati. (2013). “Peningkatan Kreativitas dan Prestasi Belajar pada Materi Minyak Bumi Melalui Penerapan Model Pembelajaran Problem Based Learning (PBL) dengan Media Crossword. Jurnal Pendidikan Kimia (JPK), 2 (4), 2013.

Santosa, P. (2005). Materi dan Pembelajaran Bahasa Indonesia. Jakarta: UT.

Shanty, I. L. dkk. (2006). Menulis (Modul). Pekanbaru: Cendikia Insani.

Slamet. (2008). Dasar-Dasar Keterampilan Berbahasa Indenesia. Surakarta: LPP dan UPT Penerbiatan dan Percetakan UNS Press.

Subana, M. (2009). Strategi Belajar Mengajar Bahasa Indonesia. Bandung: Pustaka Setia.

Tarigan, H. G. (1982). Menulis Sebagai Suatu Keterampilan Berbahasa. Bandung: Angkasa. 